Customers and Patrons of the Mad-Trade 
This series examines the development of medical knowledge and psychiatric practice from historical and sociological perspectives. The books contribute to a scholarly and critical reflection on the nature and role of medicine and psychiatry in modern societies.

I. The Regulation of Madness: Origins of Incarceration in France, by Robert Castel, translated by W. D. Halls.

2. Stubborn Children: Controlling Delinquency in the United States, I640I98I, by John R. Sutton.

3. Social Order/Mental Disorder: Anglo-American Psychiatry in Historical Perspective, by Andrew Scull.

4. Inheriting Madness: Professionalization and Psychiatric Knowledge in Nineteenth-Century France, by Ian R. Dowbiggin.

5. Madness and Social Representations, by Denise Jodelet, translated by Tim Pownall, edited by Gerard Duveen.

6. Inventing the Feeble Mind: A History of Mental Retardation in the United States, by James W. Trent, Jr.

7. Impure Science: AIDS, Activism, and the Politics of Knowledge, by Steven G. Epstein.

8. Mental Ills and Bodily Cures: Psychiatric Treatment in the First Half of the Twentieth Century, by Joel Braslow.

9. Medicalizing the Mind: The Invention of Modern Psychotherapy, by Eric Caplan.

Io. Imperial Bedlam: Institutions of Madness in Colonial Southwest Nigeria, by Jonathan Sadowsky.

I I. Undertaker of the Mind: John Monro and Mad-Doctoring in EighteenthCentury England, by Jonathan Andrews and Andrew Scull.

I2. Customers and Patrons of the Mad-Trade: The Management of Lunacy in Eighteenth-Century London, by Jonathan Andrews and Andrew Scull. 


\section{Customers and Patrons of the Mad-Trade}

The Management of Lunacy in Eighteenth-Century London

With the Complete Text of John Monro's I766 Case Book

Jonathan Andrews and Andrew Scull 
Publication of the illustrations in this book has been made possible by grants from the Scouloudi Foundation in association with the Institute of Historical Research, and from the Marc Fitch Trust.

University of California Press

Berkeley and Los Angeles, California

University of California Press, Ltd.

London, England

(C) 2003 by

The Regents of the University of California

Library of Congress Cataloging-in-Publication Data

Andrews, Jonathan, [date]-.

Customers and patrons of the mad-trade : the management of lunacy in eighteenth-century London : with the complete text of John Monro's I766 case book / Jonathan Andrews and Andrew Scull.

p. $\quad \mathrm{cm}$. - (Medicine and society ; I 2 )

Includes bibliographical references and index. ISBN 0-520-22660-7 (alk. paper)

I. Monro, John, I7I 5-I79I.

2. Psychiatrists-England-Biography.

3. Psychiatry-England-History-I 8th century.

4. Mentally ill-England-Case studies.

I. Scull, Andrew T. II. Title. III. Series.

RC450.G7 .A645 2003

6 I6.89'0092-dc2I

200206788 I

[B]

Manufactured in the United States of America
$\begin{array}{llllllllll}\text { I2 II } & \text { IO } & 09 & 08 & 07 & 06 & 05 & 04 & 03\end{array}$
IO $\quad 9 \quad 8 \quad 8 \quad 7 \quad \begin{array}{lllllll} & 9 & 5 & 4 & 3 & 2 & \text { I }\end{array}$

The paper used in this publication meets the minimum requirements of ANSI/NISO Z39.48-I 992 (R I997) (Permanence of Paper).@ 
To the memory of the late Roy Porter 
This page intentionally left blank 